\title{
Research on the Effectiveness of Political Education Based on Principles and Methods of Structural Equation
}

\author{
Jin Zhu \\ Teaching and Research Institute of Marxism \\ Yunnan University of Nationalities \\ Email: huj107@gmail.com
}

\begin{abstract}
-this paper, by means of structural equation modeling (SEM), and theoretical assumptions, uses exploratory factor and confirmatory factor to study the effectiveness of ideological and political education. The effectiveness of ideological and political education is an important issue that ideological and political education workers must face, and the teaching methods are the key factors affecting the effectiveness of ideological and political education. The results show that the effectiveness of ideological and political courses has direct and positive effects on the preferences "independent inquiry "of innovative teaching methods and has no significant impact on traditional teaching methods. This inspired the current ideological and political education to meet the real needs, to highlight the subjectivity, and to reflect practical value.
\end{abstract}

Keywords-component; structural equation modeling, political education, Marxism studies

\section{INTRODUCTION}

The teaching of political theory in higher institutes is not only the main land to carry out ideological and political education, but also is the main channel to carry out ideological and political education (Cohen, \& Arato, 1992;

Sabine, \& Thorson, 1973). Social transformation, unsettled situations and new problems, on one hand, present the modern predicament of ideological and political education; on the other hand, it also highlights the real needs and theoretical value of the research on the effectiveness of ideological and political education. Method of ideological and political education is a key factor affecting the effectiveness of ideological and political education and is the medium that other elements of ideological and political education transform from the state of readiness into the state of actual operation. Ideological and political education is not only the process that educators carry out teaching, but also the process that the educated accepts the education (Lane, 1982). From the perspective of acceptance, things with various means, ingenious methods and new forms can attract most people's attention, and are easy to be accepted. Piaget points out that good teaching can enhance students' performance, and even accelerate their spiritual growth with nothing hurt. Innovating teaching methods of ideological and political theory is an effective way to break the dilemma of ideological and political education, and meet the actual needs of contemporary college students, and has great significance on enhancing the appeal and attraction of contemporary Chinese Marxism.

This study, by means of structural equation modeling (SEM) (e.g. Bagozzi, Yi, 2012; Goldberger, 1972), investigates the application of an innovative teaching method in the course of ideological and political theory. First, teaching method of "independent inquiry" is actually the application of constructivism in the teaching of ideological and political theory. The premise of its launching is built on the fact that students have some theoretical basis. This method is to create a situation or atmosphere of problem research, to make the students under the guidance of teachers, and contact the social reality, choose and define research topics from the contents of the course of ideological and political theory, use scientific research, explore initiatively, discover and experience the problems, and draw conclusions; Second, take evaluation mechanism -combinations of evaluation from each other, their own evaluation, teacher evaluation after school, comprehensively evaluate students' demonstration in class, highlight the mainstream values, pay attention to detail changes, improve content settings ; Finally, foster students to collect, analyze, judge and summary the data, thereby enhancing their thinking and creativity, developing creative spirit and practical ability .

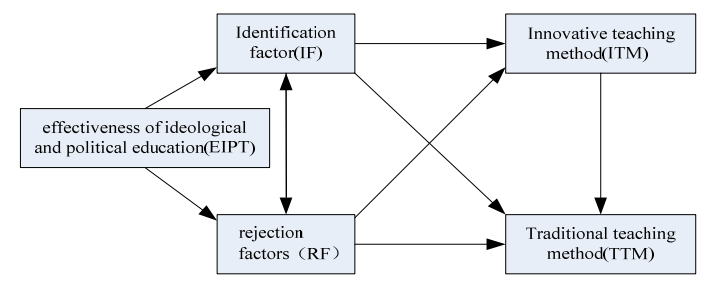

Figure 1 mechanism of the influence of effectiveness of ideological and political education on teaching methods

\section{THEORETICAL ASSUMPTIONS}

Take undergraduates of Yunnan University of Nationalities as sample, dispatch 500 questionnaires, take sampling method, sample 250 from various professional disciplines of social sciences, of which boys are 114 , girls are136 ; sample 250 from various professional disciplines of natural sciences, of which boys are137, girls are 113.306 
students are from rural areas, 194 students are from the town. 484 valid questionnaires, the effective rates are $96.8 \%$.

The questionnaire more fully reflects the contents of effectiveness of ideological and political theory, and is based on the master of literature, formed through expert interviews, group interviews and other forms. It contains test tables with 20 questions on the effectiveness of ideological and political theory, each test item uses Likert 5 scale, 1 means "strongly disagree" and 5mens "strongly agree”. Questionnaire is divided into four parts: The first part is the investigations on understanding of the course of ideological and political theory, such as the importance, learning motivation, learning attitude ; The second part is a test for the ideological and political education, such as teaching, teaching content, teaching implementation , evaluation methods ; the third part is test for the preference of the "independent inquiry" innovative teaching methods ; the fourth part is the characteristic and attribution of the investigated subject such as gender, ethnic , major, place of birth etc. . Research method is structural equation modeling (SEM), which is composed of test model and the structural model, and is an exploratory analysis method that analyzes and handles complex multivariate data.

SEM constructs contact by extracting impact factor, finds the basis of mutual restraint and affecting among the factors, the main purpose of this statistical analysis is to investigate the effects of various potential variables; it is more reliable, scientific and practical (Chen \& Tsai, 2007 ).

Factors affecting the effectiveness of ideological and political theory vary; there are internal factors and external factors. Internal factors include educators, the educated, educational objectives, content, methods, and environment; external factors are social factors including political, economic, social and cultural factors of the society. Changes in social practice, teaching, teachers' personal qualities and professional skills, school management and other aspects can improve the effectiveness of ideological and political education, and enhance the effectiveness of ideological and political education. This study suggests that, without considering social factors, teaching method is an important factor of the effectiveness of ideological and political education. The effectiveness of ideological and political education has positive correlation to the preference of "independent inquiry" innovative teaching method and has negative correlation to traditional teaching method; the degree of positive and negative correlation is affected by specific course categories. For a particular course, it can be theoretically assumed that:

A11: The effectiveness of ideological and political education has direct and positive effect on the preference of innovative teaching method;

A12: The effectiveness of ideological and political education has direct and negative effect on the preference of traditional teaching method. For attitudes towards a teaching method, there are two dimensions- identification and rejection. In general, students holding attitude of identification in ideological and political education show acceptance, love and preference towards "independent inquiry" innovative teaching method. Students holding attitude of rejection in ideological and political education show boredom, rejection and disgust towards traditional teaching method.

Thus here are the assumptions:

A21: dimension of identification of the effectiveness of ideological and political theory has direct and positive effect on the preference of innovative teaching method

A22: dimension of identification of the effectiveness of ideological and political theory has direct and negative effect on the preference of traditional teaching method

A31: dimension of rejection of the effectiveness of ideological and political theory has direct and positive effect on the preference of innovative teaching method

A32: dimension of rejection of the effectiveness of ideological and political theory has direct and negative effect on the preference of traditional teaching method.

\section{FACTOR ANALYSIS}

Using factor analysis method, and SPSS18.0 and AMOS17.0 statistical software, analyze the data obtained through survey and statistic; according to the purification standard, exclude the unqualified test items, the remaining qualified test items form a scale that analyzes the effectiveness of ideological and political Theory (EIPT).

(1) Exploratory factor analysis

Using factor analysis, carry out dimensionality reduction, the data shows seven test items are qualified, and are suitable for factor analysis , KMO value is 0.857 , the significance level of Bartlett's spherical test is less than 0.05 . From the characteristic value, the characteristic value of the previous two factors is larger than 1 , indicating that there exists two factors- identification and rejection ; from the trend of scree plot, the former two factors change in a large scale, other factors change stably, also indicating that two factorsidentification and rejection should be taken.7 question terms represent two factors- identification and rejection ( see Table 1 ) , explaining $61.60 \%$ of the information on total variance . Of which, the test items of identification factor include the fact that independent inquiry "innovative teaching methods (x1)" must be "always complied with", and "outstanding ideological and political theory should always use" independent inquiry "teaching methods (x2)", independent inquiry "teaching methods (x3)" is better to be used and adopted and "unless special circumstances, traditional teaching methods (x4)should be minimized"; the test items of rejection factor include the fact that "traditional teaching methods should be resisted (x5)", "teachers should be trained to reduce the use of traditional teaching methods (x6)" and "young teachers are not allowed to use traditional teaching methods in the classroom (x7)". Cronbach's Alpha coefficient of identification factors is 0.771 , Cronbach's Alpha coefficient of rejection factors is 0.692 , and generally acceptable level is 0.70 , so the internal consistency reliability is relatively acceptable. Minimum critical level of factor loadings is 0.60 , loadings after identification factors and rejection factors are standardized are significantly greater than 0.60 , which has stronger statistical significance, and shows strong convergent validity.

(2) Confirmatory factor analysis 
Structural stability of Table 1 needs confirmatory factor for further analysis. Through test, fit indexes that verify the model are respectively: chi-square value/ Degrees of Freedom (CMIN / DF) is 1.66, Root Mean Square Error of Approximation (RMSEA) is 0.05, Goodness of Fit Index (GFI) is 1.1, Adjusted Goodness of Fit Index (AGFI) is0.94, Comparative Fit Index (CFI) is 0.97. In general, requirements of high degree of fitting of the model are: CMIN / DF <5.0, RMSEA <0.08, GFI> 0.9, AGFI> 0.9, CFI $>$ 0.9. Therefore, the studied model has high degree of fitting, estimation of the path coefficients between the variables represents that the path coefficients are significant. Therefore, relation between identification factor, rejection factors and 7 test items is existing and stable.

TABLE 1 ANALYSIS TABLE OF EXPLORATORY FACTOR

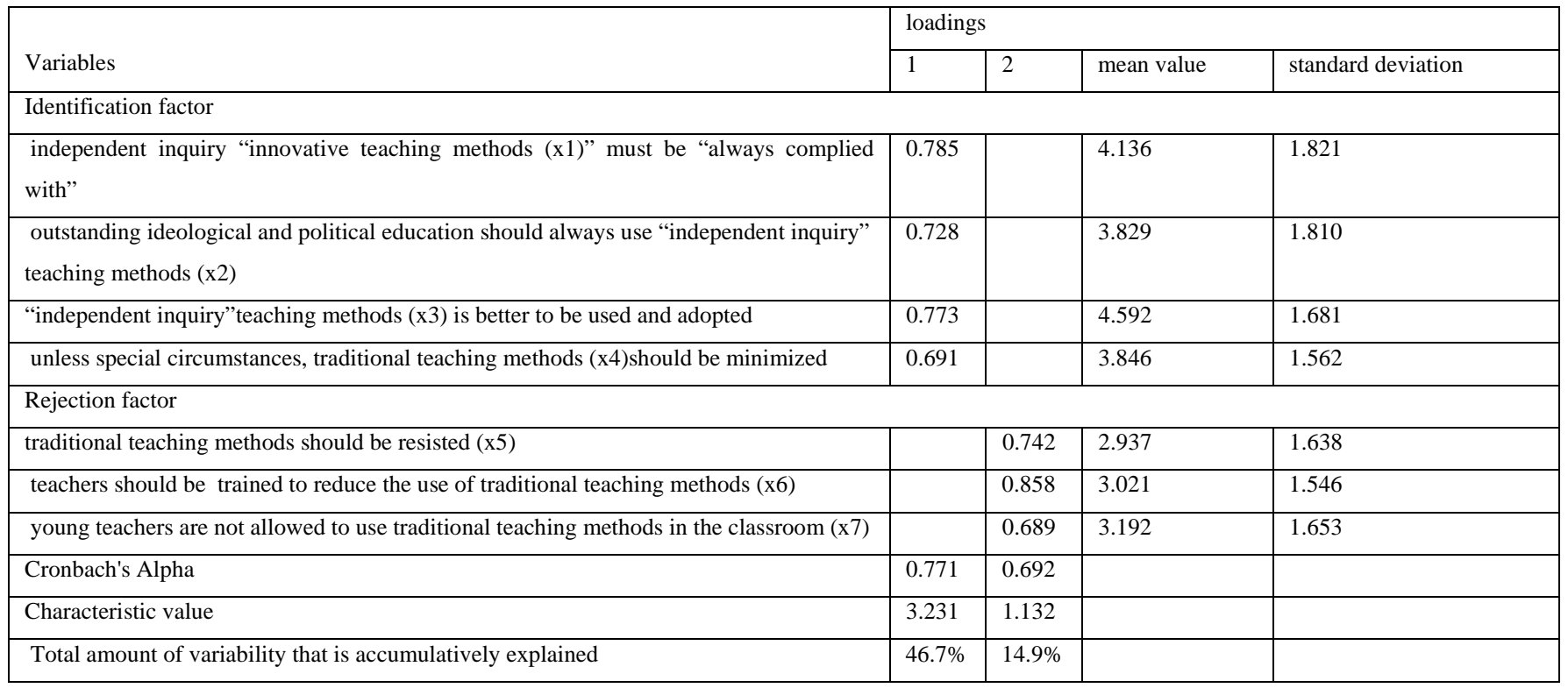

TABle 2 CORRElated ANALysis TABle

\begin{tabular}{|c|c|c|}
\hline & $\begin{array}{c}\text { effectiveness of ideological and political theory (EIPT) } \\
\text { (person correlation) }\end{array}$ & Sig. \\
\hline ITM(innovative teaching methods & $.283^{* *}$ & .000 \\
\hline (TTM) traditional teaching methods & -.084 & .091 \\
\hline
\end{tabular}

TABle 3 ESTIMATION TABLE OF COEFFICIENT

\begin{tabular}{|rr|c|c|c|}
\hline \multicolumn{2}{|c|}{ path } & C.R. & P. & path coefficient(standardized) \\
\hline ITM & IF & 3.94 & $* * *$ & .435 \\
\hline ITM & EF & -.843 & .417 & -.093 \\
\hline ITM & EF & 2.441 & .017 & .291 \\
\hline ITM & IF & -4.198 & $* * *$ & -.511 \\
\hline ITM & ITM & 6.495 & $* * *$ & .440 \\
\hline
\end{tabular}

\section{FINDINGS AND CONCLUSIONS}

(1) Results

Based on the results of this investigation, internal consistent reliability coefficient (Cronbach's Alpha) of 20 questions on the effectiveness of ideological and political theory is 0.86 , the overall average value is 53.1 and standard deviation is 13.5. it indicates that contemporary college students accept and have welcome attitudes towards innovative teaching methods of ideological and political theory, which is related to contemporary young people's personal traits that they generally agree about the reform and innovation, of course, it explains that traditional classroom teaching methods of the ideological and political education 
cannot meet the contemporary college students' real needs and is even away from their needs, and needs to be reformed and innovated. According to factor analysis, regard the sum of the scores of 7 test items as the score of Effectiveness of Ideological and Political Theory (EIPT), Innovative Teaching Methods (ITM) and Traditional Teaching Methods (TTM) are tested according to the sum of the scores of each test item, related analysis is seen in Table 2. The results show the effectiveness of ideological and political theory has positive correlation with the preference of "independent inquiry" innovative teaching methods, and has insignificant and weak correlation with the preference of traditional teaching methods (5\% significance level). Therefore, it verifies the theoretical assumptions -A11, A12.

Internal consistent reliability coefficient (Cronbach's Alpha) of 20 questions on the effectiveness of ideological and political theory that is analyzed through exploratory factor is 0.797 , the results show the effectiveness of ideological and political theory can extract identification factor and rejection factor, of which identification factor has the greatest effect on the effectiveness of ideological and political theory. Use AMOS17.0statistical software to further test the model in Figure 1, and construct a path model. Through test, fit indexes that verify the model are respectively: chi-square value/ Degree of Freedom (CMIN / DF) are 2.22, Root Mean Square Error of Approximation (RMSEA) is 0.06, Goodness of Fit Index (GFI) is 0.93, and Adjusted Goodness of Fit Index (AGFI) is0.90, Comparative Fit Index (CFI) is 0.96. Therefore, the studied model has high degree of fitting, estimation of the path coefficients between the variables is seen in Table 3, path coefficient of Identification Factor (IF) of the effectiveness of ideological and political theory for the preference of Innovative Teaching Methods (ITM) is 0.435 , which has direct positive impact ; path coefficient of Identification Factor (IF) of the effectiveness of ideological and political theory for the preference of Traditional Teaching Methods (TTM) is 0.511 , which has direct negative impact, therefore , it verifies the theoretical assumptions -A21 and A22; path coefficient of rejection Factor (EF) of the effectiveness of ideological and political theory for the preference of Innovative Teaching Methods (ITM) is- 0.093 , which has insignificant negative impact ; path coefficient of rejection factor (EF) of the effectiveness of ideological and political theory for the preference of Traditional Teaching Methods (TTM) is 0.291 , which has direct positive impact , therefore , theoretical assumptions- A31 and A32 have not been verified.

(2) Conclusion

Seen form the results, taking "independent- inquiry" innovative teaching methods enhances the effectiveness of ideological and political theory, makes a breakthrough in the reform of ideological and political education in higher institutes. Such teaching methods enhance the appeal and attractiveness of contemporary Chinese Marxism, exercise the comprehensive ability and practical ability of contemporary college students, and enhance the awareness of the problem of university students. Novel inquiry-based learning model and theory with practice are unanimously approved by the students, achieving better teaching results. Studying by "independent inquiry" innovative teaching methods, with research thinking, makes students receive comprehensive development of knowledge, ability, and ideological and moral qualities.

(3) Practical inspiration

Principle and method of Structural Equation Modeling (SEM) is a kind of multivariate statistical analysis technique which organically combines multiple regression and factor analysis methods. Because of its objectivity and reliability of data analysis, it is being widely used (Preacher, Curran , \& Bauer, 2006). But the application of SEM in ideological and political education is uncommon, choosing this approach to carry out empirical research is mainly attributed to that fact that modern ideological and political education also requires multi- disciplinary thinking, cross interaction, innovative research methods and tools to enhance the effectiveness, and come out of modern position. It should be noted that SEM analysis must be based on strict test of variables and actual work (Barrett, 2007); otherwise it will have no practical significance. Results of data analysis reflect that inquiry teaching method allows students to become active recipients of knowledge, develops students' initiative and creativity, highlights the subjectivity and becomes quite effective teaching model that students love. This inspired the current ideological and political education to have "indomitable spirit", to adapt to the practical needs that knowledge-based economy age requires innovative talents, to solve practical problems, to reflect the practical value, to implement "people-oriented", to advocate the principle of subjectivity ; to transfer traditional single, other-domain , passive way of learning into diverse, independent, active way of learning. It also reflects the indirect shift of the subjectivity of ideological and political education is necessary requirement of the times.

\section{REFERENCES}

[1] Cohen, J.L. \& Arato, A. (1992). Civil society and political theory. Cambridge, MA: MIT Press.

[2] Sabine, G.H. \& Thorson, T.L. (1973). A history of political theory. 4th edn. Hinsdale, IL: Dryden Press.

[3] Lane, R.E. (1982). Government and self-esteem: Should government be concerned with selfesteem?, Political Theory 10(1): 5-31

[4] Chen, C.-F., \& Tsai, D. (2007). How destination image and evaluative factors affect behavioral intentions? Tourism Management, 28, 1115-1122.

[5] Bagozzi, R.; Yi, Y. (2012) "Specification, evaluation, and interpretation of structural equation models". Journal of the Academy of Marketing Science, 40 (1), 8-34.

[6] Goldberger, A. S. (1972). Structural equation models in the social sciences. Econometrica 40, 979- 1001.

[7] Preacher, K. J., Curran, P. J., \& Bauer, D. J. (2006). Computational tools for probing interaction effects in multiple linear regression, multilevel modeling, and latent curve analysis. Journal of Educational and Behavioral Statistics, 31, 437-448.

[8] Barrett, P. (2007). Structural equation modelling: adjudging model fit. Personality and Individual Differences, 42, 815-824. 